\title{
In Memoriam: Osamu Fujimura
}

Osamu Fujimura (born on August 29, 1927 in Tokyo, died on March 13, 2017 in Hawaii) was a physicist, phonetician, speech scientist, and linguist, who contributed to the foundation of modern phonetic sciences. Osamu received his DSc in Physics from the University of Tokyo in 1962. After his graduation, he worked with Morris Halle and Ken Stevens at MIT, and later with Gunnar Fant at the Royal Institute of Technology, Stockholm, Sweden. Between 1965 and 1973, he served as the director of the Research Institute of Logopedics and Phoniatrics (RILP), at The University of Tokyo, where he developed advanced techniques for studying articulation of speech, including EMG and the X-ray microbeam system [1]. In

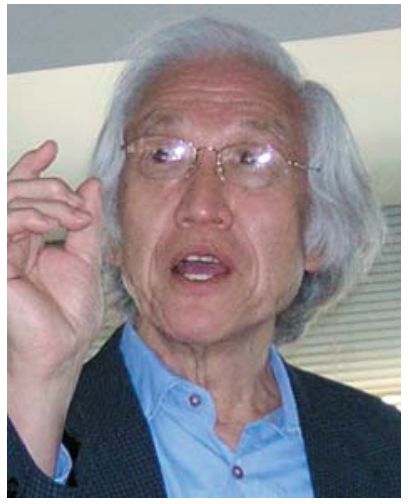

Osamu Fujimura 1973, Osamu moved to AT\&T Bell Laboratories, Murray Hill, NJ, USA, where he worked with many young researchers, including Mary Beckman, Jan Edwards, Jo Estill, Sue Hertz, Julia Hirschberg, Marian Macchi, Mitch Marcus, Joan Miller, Mark Liberman, Julie Lovins, Janet Pierrehumbert, Jacqueline Vaissière and others, and is remembered for encouraging many young scientists. Osamu moved to the Department of Speech \& Hearing Science at The Ohio State University in 1988. He continued to teach and conduct research until he retired as Professor Emeritus in 2003. The students/colleagues he mentored at OSU include Donna Erickson, John Josephson, Kevin Lenzo, Caroline Menezes, Kerrie Beechler Obert, Bryan Pardo, Reiner Wilhelms-Tricarico, and Chao$\mathrm{Min} \mathrm{Wu}$. Even after his retirement, he continued his passion for phonetic research.

It is difficult to list all the contributions he made to the field of speech science, because he contributed so much. He published many articles in prominent journals, including The Journal of the Acoustical Society of America, Journal of Phonetics, Language and Speech, and Phonetica [2,3]. He is perhaps best known for his collaboration to apply X-ray technologies to study human articulation patterns and for his contributions to the foundation of modern acoustic and articulatory analyses of speech, including understanding the acoustics of nasal consonants and speech perception. His collaborators include, but are not limited to, Maki Aoyagi, Hiroya Fujisaki, S.I. Harada, Shosuke Haraguchi, Shiro Hattori, Minoru Hirano, Hajime Hirose, Kiyoshi Honda, Haruhisa Ishida, Kenji Itoh, Kuniko Miyawaki Kakita, Yuki Kakita, Ryohei Kagaya, Hideki Kawahara, Shigeto Kawahara, Shigeru Kiritani, Olle Kjellin, Yasuyuki 
Konparu, S.Y. Kuroda, William Leben, Ilse Lehiste, Jan Lindqvist-Gauffin, Shinji Maeda, Michinao Matsui, Amanda Miller, Seiji Niimi, John Ohala, Richard Sproat, Toshiyuki Sadanobu, Sumiko Sasanuma, Masayuki Sawashima, Zyun-ichi Simada, Miyako Sugito, Johann Sundberg, Teruyo Suzuki, Yoh'ichi Tohkura, Hidetoshi Takahashi, Itaru F. Tatsumi, and J.C. Williams. Beyond his contribution to phonetic sciences, he wrote a review of Syntactic Structures in Japanese in 1963, thereby helping to introduce generative linguistics in Japan. He also developed a model of speech articulation and phonetic implementation, "the C/D model," in which phonological specifications are "converted" and "distributed" to multiple articulators.

However, perhaps an even more pervasive and lasting contribution than what Osamu actually did as a scientist is how he encouraged others in his research labs and beyond, especially young researchers, women and men, to observe data, ask good questions, think about how to interpret and organize their observations, and then to cheer them on as they became independent researchers, contributing to the field of speech and other sciences. As we remember Osamu, may we all be as willing as he was to share time, energy, expertise, and mentoring with the succeeding generations.

There is a website to share our memories of Osamu; those who would like to share theirs are very much encouraged to contribute [4]. We also very sincerely apologize for not mentioning by name everyone Osamu's life touched.

藤村靖 (1927/8/29-2017/3/13) は物理学者, 音声科学者, 言語学者であり, 現 代の音声科学の基礎作りの一役を担った偉大な研究者である. 藤村先生は1962 年に東京大学から博士号 (物理) を取得後, MIT で Morris Halle, Ken Stevens, ス ウェーデンの Royal Institute of Technology で Gunnar Fant と研究を進めた. その 後, 1965 年から 1973 年にかけて, 東京大学医学部に設置された音声・言語医学 研究施設 (Research Institute of Logopedics and Phoniatrics: RILP) の教授を務めた. 任期中, 藤村先生は音声の分析に近代科学を応用する手法の開発を続け, 喉頭 筋電, X線マイクロビームなどを用いた音声の生理学的研究を精力的に行った [1]. 1973 年に、ニュージャージー州のAT\&T Bell Laboratories に移り, 数多くの 研究者と共同研究を続け，また同時に，当時の若い科学者たちの指導も行った. 当時藤村先生と共同で研究を行った研究者には Mary Beckman, Jan Edwards, Jo Estill, Sue Hertz, Julia Hirschberg, Marian Macchi, Mitch Marcus, Joan Miller, Mark Liberman, Julie Lovins, Janet Pierrehumbert, Jacqueline Vaissière など鋝々たる方々 が名を連祆ている. 1988 年に, オハイオ州立大学に教授として就任し, 研究・ 教育を続けた。当時の学生には Donna Erickson, John Josephson, Kevin Lenzo, Caroline Menezes, Kerrie Beechler Obert, Bryan Pardo, Reiner Wilhelms-Tricarico, Chao-Min Wu などがいる. 2003 年に名誉教授として大学を退官したが, 退官後 も精力的に音声科学の研究に邁進した.

藤村先生の研究は多岐にわたり，この限られた紙面でそれら全てを紹介す ることは出来ないが, 音声学の主要な国際雑誌に多くの論文を出版している $[2,3]$. 藤村先生の業績の中でよく知られているのが，X線マイクロビームを用いた調 音運動の研究, 1960 年代に行われた音響分析の基礎研究であろう. 特に彼の鼻 音の音響的特徵の生成機構を明らかにした研究は世界的に有名である。また， 藤村先生はフォルマントに基づく母音知覚をはじめ, 数多くの貴重な知見をも たらした知覚実験や Analysis-by-Synthesis に基づく音声合成の研究も行なって いる.さらに,これらの音声学に対する貢献だけでなく, チョムスキーの統語理 論を日本に紹介したのも藤村先生である. また, 彼のキャリアの後半では“the 
C/D model” と呼ばれる, 抽象的な音韻情報を具体的な調音動作にマッピング するモデルを提唱した。彼の研究の一端は2007年に執筆された『音声科学原 論一言語の本質を考える』(岩波書店) で知ることができる. 上記の研究者に 加え, 藤村先生と共同で研究を行った人には Maki Aoyagi, Hiroya Fujisaki, S.I. Harada, Shosuke Haraguchi, Shiro Hattori, Minoru Hirano, Hajime Hirose, Kiyoshi Honda, Haruhisa Ishida, Kenji Itoh, Kuniko Miyawaki Kakita, Yuki Kakita, Ryohei Kagaya, Hideki Kawahara, Shigeto Kawahara, Shigeru Kiritani, Olle Kjellin, Yasuyuki Konparu, S.Y. Kuroda, William Leben, Ilse Lehiste, Jan Lindqvist-Gauffin, Shinji Maeda, Michinao Matsui, Amanda Miller, Seiji Niimi, John Ohala, Richard Sproat, Toshiyuki Sadanobu, Sumiko Sasanuma, Masayuki Sawashima, Zyunichi Simada, Miyako Sugito, Johann Sundberg, Teruyo Suzuki, Yoh'ichi Tohkura, Hidetoshi Takahashi, Itaru F. Tatsumi, J.C. Williams などがおり, 藤村先生の積極的な共同研 究への姿勢が窥い知れる.

藤村先生は彼自身の研究そのものにとどまらず, 他の研究者たちと積極的 に交流し, 大きな影響を与えた. 藤村先生は, キャリアの長さや性別などを全く 気にせず，現象をしっかりと観察し，そこからどのような問題が導き出される かを考え，現象から何が見えてくるのかを観察することで，若い研究者に音声 科学の方法論を学ばせた。また, それぞれの研究者が音声科学や言語学の分野 で独り立ちしていけるように指導を続けた. 後進の若手の学者たちに時間を惜 しまず，指導を続けていくことが，藤村先生の遺志を引き継ぐことになるだろ う.

藤村先生との思い出を共有するためのウェブサイトをご家族が管理して いるので,生前の藤村先生と交流のあった方々は是非投稿していただきたい [4]. また, この限られた紙面において藤村先生と生前に親交があった人すべての名 前を上げるのは不可能であった. 謹んでお詫びを申し上げる.

Donna Erickson, New Haven, CT Shigeto Kawahara, Tokyo

\section{References}

1 RILP: Annual Bulletin: http://www.umin.ac.jp/memorial/rilp-tokyo/.

2 Bibliography of Osamu Fujimura by Kikuo Maekawa. 2014. https://cdmodel.files.wordpress.com/ 2015/10/of-biblio.pdf.

3 Overview of Osamu Fujimura's work by Kiyoshi Honda. http://fujimurainstitute.org/osamu/.

4 Remembering Osamu Fujimura: http://fujimurainstitute.org/osamu/. 
